\title{
POTENSI DAN STATUS KERENTANAN TERUMBU KARANG DI PERAIRAN PELITA JAYA KABUPATEN SERAM BAGIAN BARAT PROVINSI MALUKU
}

\author{
Masudin Sangaji \\ Jurusan Manajemen Sumberdaya Perairan Unpatti Ambon \\ Email: ms.unpatti@gmail.com
}

\begin{abstract}
Abstrak: Berbagai aktifitas antropogenik yang dilakukan di perairan Pelita Jaya telah merubah ruang perairan yang awalnya di dominasi terumbu karang mulai tampak di dominasi oleh patahan karang (rubble) dan makroalga. Penentuan status kategori kerentanan berbasis pada persen tutupan karang dengan mengacu pada tabel kriteria kategori kerentanan. Hasil penelitian menunjukan kondisi perairan Pelita Jaya sangat mendukung bagi pertumbuhan dan perkembangan terumbu karang. Perairan Pelita Jaya memiliki potensi taksa karang batu yang terdiri atas 83 spesies karang batu yang termasuk dalam 34 genera dan 14 family, serta memiliki komponen penyusun terumbu karang yang terdiri atas tiga komponen utama abiotik, yaitu Sand (S), Rubble (R) dan Rock (RCK), dimana R dan RCK mendominasi komponen abiotik. Status terumbu karang di perairan Pelita Jaya umumnya berada pada kategori kerentanan tinggi. Bila tekanan antropogenik terus terjadi maka status terumbu karang akan berubah menjadi kerentanan sangat tinggi.
\end{abstract}

\section{Kata Kunci: Kerentanan, Terumbu Karang, Pelita Jaya}

\section{THE ALL THE POTENTIAL AND THE STATUS OF THE SUSCEPTIBILITY OF THE CORAL REEFS OF THICK IN THE WATERS PELITA JAYA DISTRICT SERAM BAGIAN BARAT PROVINCE MALUKU}

\begin{abstract}
A variety of antropogenik activities carried on in waters pelita jaya has changed space of waters that originally in domination coral reefs begin to seem in domination by the fault coral (rubble) and makroalgae. Category vulnerability of the process based on the percent veils coral with reference to table the criteria for the category of vulnerability. The results of the study showed the condition of pelita jaya waters is highly supportive of growth and development for coral reefs. Thick in the waters pelita jaya has the all the potential of taxa hooked up with a rock sponge soaked it with vinegar which is made up of 83 species coral stone which after putting it included in 34 genera and the class group cannot be 14, as well as having component parts a constituent of a coral reef on which consists of three among the main components of abiotik, the are sand (S), rubble (R) and rock (RCK), where $\mathrm{R}$ and $\mathrm{RCK}$ dominated up to that moment a component abiotik. The status of the coral reefs of thick in the waters pelita jaya are generally located into the
\end{abstract}


category of a vulnerability of the high. If pressure antropogenik continue to happen and the covert status of to coral reefs as a shall be turned into a vulnerability of the very high

\section{Keywords: Susceptibility, Coral Reefs, Pelita Jaya}

Keanekaragaman hayati laut menjadi salah satu isu global dalam membahas masalah lingkungan, termasuk ekosistem terumbu karang di lingkungan pesisir. Hal ini karena ekosistem terumbu karang memiliki keanekaragaman hayati tinggi yang didalamnya hidup berbagai biota laut bernilai ekonomis. Ekosistem terumbu karang merupakan ekosistem yang sangat rentan dan memiliki daya pulih yang rendah bila terjadi tekanan lingkungan. Luas terumbu karang Indonesia mencapai $58.707 \mathrm{~km}^{2}$, dimana sekitar $70 \%$ adalah terumbu karang tepi, 20\% terumbu penghalang, 2,5\% atol dan 7,5\% Patch Reef (Tuwo, 2011).

Terumbu karang yang baik berada di kawasan Timur Indonesia, terutama di pulau-pulau kecil seperti Maluku, Maluku Utara, Sulawesi Selatan dan Nusa Tenggara (Sukarno et al., 1981). Kenyataan ini menyebabkan Indonesia ditetapkan sebagai pusat keragaman hayati terumbu karang dunia karena berada di pusat Segitiga Terumbu Karang. Menurut Monk et.al., (2000), terumbu karang di Indonesia mengalami penurunan kualitas sangat cepat. Hal ini berkaitan dengan sifat alaminya yang sensitif dan mudah rusak bila mendapat tekanan lingkungan secara permanen.

Ekosistem terumbu karang memiliki produktivitas hayati yang tinggi, sumber bahan makanan, obat-obatan, dan bahan konstruksi (Suharsono, 2008). Secara ekologi, terumbu karang berfungsi sebagai tempat tinggal, tempat mencari makan, tempat memijah, tempat asuhan, dan tempat berlindung berbagai biota laut, serta sebagai pemecah gelombang. Dari segi ekonomi, terumbu karang berfungsi sebagai penyedia sumberdaya perikanan, plasma nutfah bahan farmasi dan industri kosmetik, bahan bangunan, serta area ekowisata bahari. secara sosial ekosistem terumbu karang berfungsi sebagai tempat masyarakat pesisir melakukan aktifitas penangkapan sumberdaya perikanan, tempat berlangsungnya aktifitas sosial masyarakat bagi penerapan kearifan lokal (local wisdom), menyedia jasa-jasa lingkungan untuk kegiatan wisata bahari seperti diving dan snorkling, tempat berlangsungnya kegiatan penelitian, dan sebagai objek peneltian dan pembelajaran.

Menyadari peran dan fungsi terumbu yang sangat besar bagi ekosistem perairan laut maka data dan informasi serta kondisi terumbu karang di suatu wilayah sangat penting untuk diketahui dan dimiliki bagi kepentingan pengelolaan terumbu karang secara berkelanjutan. Salah satu langkah terbaik untuk mengetahui data dan informasi serta kondisi terumbu karang adalah dengan melakukan penelitian tentang potensi dan status kerentanan terumbu karang. Salah satu daerah yang memiliki potensi terumbu karang adalah perairan Pelita Jaya yang terletak Kabupaten Seram Bagian Barat Provinsi 
Maluku. Terumbu karang di perairan Pelita Jaya menarik untuk diteliti karena tingginya tekanan lingkungan akibat aktifitas pembangunan di pesisir pantai (maind land) dan di sekitar ekosistem terumbu karang yang sudah tentu akan mengancam kelestarian terumbu karang.

Berbagai aktifitas antropogenik yang dilakukan di perairan Pelita Jaya telah merubah ruang perairan pada kedalaman $2-15$ meter yang awalnya di dominasi terumbu karang, namun sejak 5-10 tahun terakhir mulai tampak di dominasi oleh patahan karang (rubble) dan makroalga. Kondsi ini tentu menjadi ancaman bagi ekosistem terumbu karang di Pelita Jaya khususnya keanekaragaman dan kekayaan taksa terumbu karang yang dimiliki. Disamping itu, spesies karang yang di kategorikan dilindungi yang sampai saat ini belum terinformasi dengan baik sementara spesies karang tersebut sangat penting untuk diketahui bagi keperluan konservasi dan pengelolaan terumbu karang masa depan. Untuk itu, penelitian tentang potensi dan status kerentanan terumbu karang di perairan Pelita Jaya, menjadi relefan untuk dilakukan.

\section{METODE PENELITIAN}

Penelitian ini dilakukan di perairan Pelita Jaya Kabupaten Seram Bagian Barat Provinsi Maluku. Penelitian dilaksanakan pada Bulan Juli 2015. Peta lokasi penelitian ditampilkan pada Gambar 1.

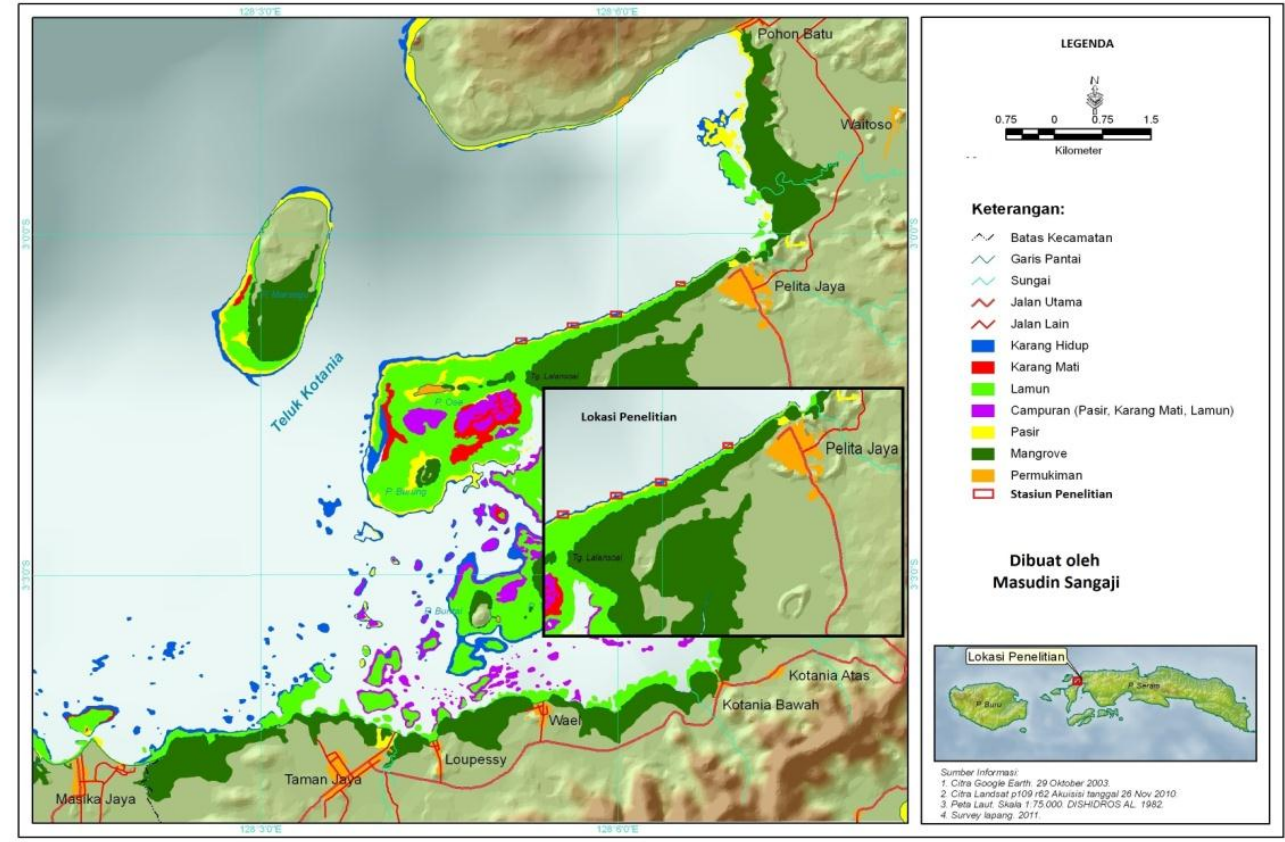

Gambar 1. Lokasi Penelitian Di Perairan Pelita Jaya

Penelitian ini bersifat kuantitatif deksriptif. Jenis data yang dikumpulkan dalam penelitian ini adalah data primer dan sekunder. Data primer diperoleh melalui observasi

BIOLOGI SEL (VOL 6 NO 1 EDISI JAN-JUN 2017 ISSN 2252-858X/E-ISSN 2541-1225) PAGE 28 
lapangan, yaitu kondisi eksisting terumbu karang. Data sekunder diperoleh melalui penelusuran pustaka, dokumen hasil-hasil penelitian sebelumnya yang relevan dengan masalah penelitian.

Data Suhu dan salinitas air di tiap lokasi (stasiun) terumbu karang diukur in situ memakai thermometer batang dan refractometer. Pada bagian lain, kecerahan air diukur menggunakan Sechi Disk pada perairan lokasi terumbu karang yang relatif dalam. Data hasil pengukuran suhu, salinitas dan kecerahan air dicatat pada lembaran data. Untuk mendapatkan data potensi terumbu karang dilakukan pengamatan terhadap komponen penyusun terumbu. Pengumpulan data terumbu karang tiap stasiun penelitian diperoleh memakai Metode LIT (Line Intercept Transect Method) menurut English et.al. (1997). Dengan menggunakan peralatan selam, roll meter dengan panjang $50 \mathrm{~m}$ garis transek di letakan di zona tepi tubir sejajar garis pantai, kemudian dicatat data panjang perpotongan komponen penyusun terumbu (biotik dan abiotik) dengan tahapan sebagai berikut:

1. Komponen biotik, yaitu berbagai bentuk tumbuh koloni karang batu dan biota laut lain (soft corals, algae halimeda, turf algae, spons, ekhinodermata, moluska, gorgonia dan DCA) yang dilintasi transek diukur panjang perpotongannya $(\mathrm{cm}, \mathrm{mm})$.

2. Komponen abiotik yang meliputi patahan karang mati, karang mati, pasir, dan batuan diukur dan dicatat panjang perpotongannya dalam $\mathrm{cm}$ atau $\mathrm{mm}$.

3. Data perpotongan komponen biotik dan abiotik yang dicatat pada underwater plastic slate, dipindahkan ke lembaran data untuk tabulasi dan analisis data.

4. Spesies dan bentuk karang batu pada areal transek dan sekitarnya difoto untuk dianalisis komposisi taksa karang batu pada tiap stasiun penelitian.

Hasil pengukuran kondisi suhu, salinitas dan kecerahan perairan ditabulasi, selanjutnya ditampilkan dalam bentuk tabel, kemudian dibahas menggunakan pendekatan statistik deskriptif, serta dihubungkan dengan peranannya terhadap pertumbuhan dan perkembangan karang batu dan terumbu karang. Komponen penyusun, presentasi tutupan, dan komposisi taksa karang diperoleh dengan menganalisis hasil foto sampel karang pada tiap areal sampling yang diidentifikasi dan disusun komposisi taksanya menggunakan Suharsono (2008). Data panjang perpotongan komponen penyusun terumbu ditabulasi menurut stasiun maupun gabungan stasiun penelitian dalam format program excel. Melalui tabulasi data tersebut, nilai persen tutupan substrat dasar terumbu oleh bentuk-bentuk tumbuh karang, biota bentik lain, dan komponen abiotik dihitung dengan formula dari English et.al. (1997), yaitu:

$$
\mathrm{Pt}=\frac{P j c}{P j t} \times 100
$$

Dimana: $\mathrm{Pt}=$ persentutupan $P j c=$ panjangkategori Pjt= panjangtransek.

Status kerentanan terumbu karang perairan Pelita Jaya ditentukan berdasarkan dimensi kerentanan ekologi dengan melihat persen tutupan karang. Kategori kelas kerentanan dibagi menjadi 5 kelas kerentanan yaitu extrime vulnarability, highly 
vulnaribility, low vulnaribility, dan no vulnarability. Ukuran persen tutupan karang yang dijadikan sebagai indikator kerentanan yaitu dengan memodifikasi kriteria baku penilaian kerusakan terumbu karang KEPMENEG-LH No. 4 Thn 2001. Hasil modifikasi kemudian dijadikan sebagai ukuran status kerentanan terumbu karang. Persen tutupan karang dan kategori kerentanan terumbu karang ditampilkan pada Tabel berikut.

Tabel 1. Penilaian Status Kerentanan Terumbu Karang

\begin{tabular}{|c|l|}
\hline Tutupan Terumbu Karang $(\%)$ & \multicolumn{1}{c|}{ Kategori Kerentanan } \\
\hline $0.01-24.99$ & Extrime vulnerability/kerentanan sangat tinggi \\
\hline $25-49.99$ & Highly vulnerability/kerentanan tinggi \\
\hline $50-74.99$ & Low vulnerability/kerentanan rendah \\
\hline $74.99<$ & No vulnerability/tidak rentan \\
\hline
\end{tabular}

\section{HASIL DAN PEMBAHASAN}

Hasil analisis genera karang dengan jumlah spesies tertinggi dimiliki oleh Acropora (26 spesies), Porites (11 spesies), Montipora (7 spesies), Fungia (6 spesies) dan Goniastrea (5 spesies). Selain itu, 16 genera karang memiliki jumlah spesies rendah (1 spesies). Dalam hal ini, bila terumbu karang mendapat tekanan pemanfaatan intensif, maka 16 marga karang dengan kakayaan spesies rendah itu terancam hilang. Ditinjau dari luas terumbu dan kondisi lingkungan, maka kekayaan spesies karang Dusun Pelita Jaya tergolong cukup tinggi. Komposisi taksa karang dan sebarannya di perairan Pelita Jaya dapat dilihat pada Gambar 2.

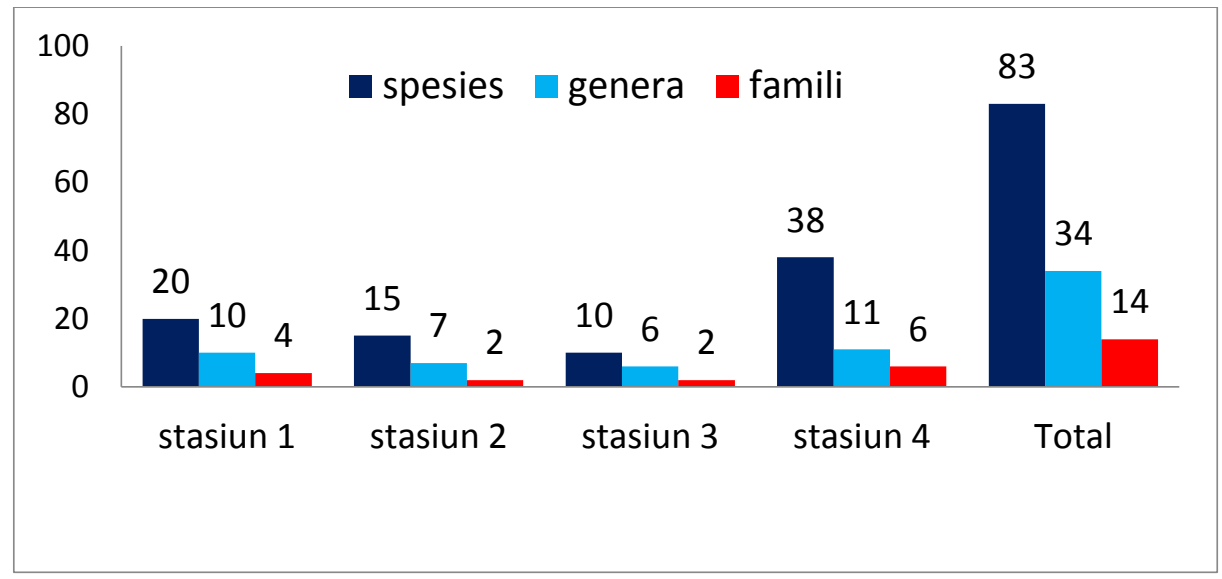

Gambar 2. Komposisi Taksa Karang Batu Antar Stasiun Terumbu Karang.

Sesuai data komposisi taksa karang dan sebarannya antara Stasiun (ST), maka kekayaan spesies, genera dan famili karang yang tinggi berada di ST4, diikuti ST1, dan terendah di areal terumbu ST3. Hal ini berarti preferensi substrat dasar terumbu ST4 menunjang kehadiran beragam taksa karang, tetapi terumbu ST3 yang mendapat tekanan pemanfaatan tinggi maka kekayaan taksa karangnya rendah. Berdasarkan data komposisi taksa karang, ternyata 14 spesies karang menyebar luas atau bisa ditemukan di empat stasiun pengamatan. Spesies karang yang menyebar luas itu adalah Acropora digitifera, 
A. divaricata, A. florida, A. humilis, A. pulchra, A. tenuis, Fungia concina, F. fungites, Seriatopora hystrix, Porites lutea, $P$. cylindrica, $P$. lobata, $P$. meyeri dan $P$. solida.

Secara alami, harusnya kondisi terumbu karang perairan Pelita Jaya dalam kondisi sangat baik, namun akibat tekanan antropogenik disekitar telah menjadikan terumbu karang dalam kondisi rusak. Menurut Sangaji (2012) tutupan terumbu karang perairan Pelita Jaya berkisar dari 50,64\%-70,23\%, namun saat ini menurun menjadi 39,98\%$56,04 \%$. Kondisi ini akan menurun secara berkala seiring dengan semakin tingginya kegiatan antropogenik masyarakat yang berada di wilayah pesisir Pelita Jaya. Aktivitas manusia dapat mengancam penurunan kondisi terumbu (Burke et.al, 2002) juga terjadi di terumbu karang Dusun Pelita Jaya. Hal ini menyebabkan kondisi terumbunya telah menurun ke kategori Baik, dan mungkin akan ke kategori Rusak.

Tabel 2. Status kerentanan terumbu karang di perairan Dusun Pelita Jaya

\begin{tabular}{lccl}
\hline \multicolumn{1}{c}{ Stasiun } & $\begin{array}{c}\text { Presentasi } \\
\text { Tutupan }\end{array}$ & $\begin{array}{c}\text { Kriteria } \\
\text { Kerentanan (\%) }\end{array}$ & \multicolumn{1}{c}{ Kategori Kerentanan } \\
\hline Stasiun 1 & 53,58 & $50-74.9$ & Low vulnerability/kerentanan rendah \\
Stasiun 2 & 45,38 & $25-49.9$ & Highly vulnerability/kerentanan tinggi \\
Stasiun 3 & 56.04 & $50-74.9$ & Low vulnerability/kerentanan rendah \\
Stasiun 4 & 39.98 & $25-49.9$ & Highly vulnerability/kerentanan tinggi \\
\hline Jumlah & 47.64 & $25-49.9$ & Highly vulnerability/kerentanan tinggi \\
\hline
\end{tabular}

Berdasarkan presentasi tutupan, maka terumbu karang di perairan Pelita Jaya pada umumnya berada dalam kategori Highly vulnaribility (kerentanan tinggi). Sesuai nilai persen tutupan karang, maka secara spasial kondisi terumbu karang di areal terumbu ST2 dan ST4 telah berada pada kategori kerentanan tinggi, sementara kondisi terumbu pada ST3 dan ST1 berada pada kategori Low vulnaribility (kerentanan rendah) tetapi telah mendekati Highly vulnaribility (kerentanan tinggi). Bila tekanan antropogenik terus terjadi di areal terumbu ST3 dan ST1, maka kondisi terumbunnya akan masuk kategori Extrime vulnerability (kerentanan sangat tinggi) yang mengarah pada kerusakan terumbu karang pada skala yang lebih besar yang berujung pada kepunahan. Fakta ini menunjukan bahwa degradasi terumbu karang perairan Pelita Jaya membutuhkan langkah-langkah pengelolaan yang dapat mengurangi kegiatan antropogenik di lingkungan sekitarnya.

\section{Kondisi Lingkungan Perairan Terumbu Karang}

Rerata suhu air terumbu karang berada pada kisaran optimum pertumbuhan karang batu dan perkembangan terumbu (Supriharyono, 2007), yakni $28{ }^{\circ} \mathrm{C}-29{ }^{\circ} \mathrm{C}$. Suhu perairan terumbu karang ini mencirikan perairan hangat dan menunjang pertumbuhan karang maksimum (Dahuri $d k k$. 2008). Nilai rerata salinitas sekitar terumbu karang adalah 32,25 ppt. Supriharyono (2000) mengatakan polip karang hidup subur pada salinitas air laut antara 24-36\% dan karang tumbuh baik pada perairan dengan salinitas 30-35 ppt (Dahuri $d k k, 2008$ ). Dalam hal ini, suhu dan salinitas di perairan pantai Dusun Pelita Jaya tergolong baik bagi pertumbuhan karang dan perkembangan terumbu.

Pengamatan visual menunjukan kecerahan perairan terumbu karang Dusun Pelita 
Jaya tergolong tinggi, dan seakan tidak mengalami sedimentasi (Dahuri dkk, 2008). Sebaliknya, perairan terumbu karang ST2 tampak keruh dan tampak tecemar minyak yang diduga bersumber dari kapal-kapal motor yang berlabuh di dermaga/jetty di sekitar areal terumbu karang. Hal ini terbukti pada hasil analisis, yaitu kondisi terumbu karang ST2 telah berada pada kategori Rusak. Kecerahan air menentukan penetrasi matahari ke kolom air dan membatasi karang batu yang bergantung pada fotosintesis zooxanthelae pada jaringan polip untuk produksi $\mathrm{O}_{2}$ dan makanan bagi karang (Levinton, 1999).

\section{Potensi Terumbu Karang di Perairan Pelita Jaya}

\section{a. Komposisi Taksa Karang Batu}

Melalui transek dan inventarisasi pada empat stasiun penelitian, ditemukan 83 spesies karang batu yang termasuk dalam 34 genera dan 14 famili. Famili karang batu dengan kekayaan spesies tinggi adalah Acroporidae (38 spesies), Faviidae (20 spesies), Fungiidae (11 spesies), Poritidae (11 spesies), dan yang terendah adalah Caryophyllidae, Merulinidae dan Mussidae memiliki kekayaan spesies terendah (1 spesies). Kondisi ini sesuai dengan pernyataan Suharsono (1996), yaitu famili Acroporidae, Faviidae, Fungiidae dan Poritidae memiliki kekayaan spesies tinggi di perairan Indonesia. Kenyataan ini memberi gambaran bahwa komunitas terumbu karang yang mendiami perairan pesisir dan pulau-pulau kecil di Maluku memiliki kekayaan spesies tertinggi yang didominasi oleh 4 famili yaitu Acroporidae, Faviidae, Fungiidae dan Poritidae, sedangkan kekayaan spesies terendah dimiliki oleh 3 famili yaitu Caryophyllidae, Merulinidae dan Mussidae. Dihubungkan dengan pendapat Nybakken (2001), maka 14 spesies karang dengan sebaran luas ini mampu beradaptasi dengan kondisi lingkungan biofisik terumbu karang di perairan Pelita Jaya.

Sebanyak 32 spesies karang batu menyebar terbatas. Famili karang dengan spesies menyebar terbatas di dominasi oleh Acroporidae (12 spesies) dan Faviidae (9 spesies). Secara spasial, terumbu karang ST4 memiliki spesies karang dengan sebaran terbatas yang tinggi (12 spesies), diikuti ST1 (9 spesies) dan ST2 (8 spesies), tetapi terumbu karang ST3 hanya memiliki 3 spesies karang dengan sebaran terbatas. Bila uaraian ini dikaitkan dengan pendapat Nybakken (2001), maka habitat mikro terumbu karang menentukan kehadiran spesies karang dengan sebaran terbatas.

\section{b. Komponen Penyusun Terumbu Karang}

Hasil penelitian menunjukan bahwa komponen biotik memiliki persen tutupan lebih tinggi dibanding komponen abiotik. Komponen biotik adalah komponen penyusun utama terumbu karang Dusun Pelita Jaya. Persen tutupan komponen biotik lebih tinggi pada semua areal terumbu, dan persen tutupan karang batu lebih tinggi dari komponen biotik lain di semua areal terumbu. Secara rinci, persen tutupan karang di ST3 lebih tinggi, walaupun bentuk tumbuh karangnya kurang variatif. Hal ini akibat persen tutupan karang Acropora bentuk tumbuh ACB tergolong tinggi pada ST 3. Persen tutupan karang di areal 
terumbu ST1 juga tinggi karena ada kontribusi nilai persen tutupan karang batu dari bentuk tumbuh CM, ACB dan ACT.

Hasil analisis menunjukan persen tutupan Coraline Alga, Macroalgae dan Turf Algae lebih tinggi di areal terumbu ST 2 dan ST 3 dibanding ST1 dan ST2 (Tabel 4.7). Komponen lain (OT) menempati keempat areal terumbu yang diteliti, dengan persen tutupan yang tinggi di areal terumbu ST4. Spons hanya ditemukan di areal terumbu ST1 dan ST4 dengan persen tutupan rendah, sementara soft coral tidak ditemukan di areal terumbu ST2 dengan persen tutupan yang tinggi di areal terumbu ST4. Persen tutupan karang mati ditutupi (DCA) lebih tinggi di areal terumbu ST2, semntara persen tutupan karang mati (DC) tergolong tinggi pada ST1, ST4 dan ST 3.

Terumbu karang Dusun Pelita Jaya disusun tiga komponen utama abiotik, yaitu sand (S), rubble (R) dan Rock (RCK), dimana R dan RCK mendominasi komponen abiotik. Hasil ini disokong oleh Sangaji (2012) yang menyatakan komponen utama abiotik di perairan terumbu karang Pelita Jaya terdiri atas sand (pasir), rubble (patahan karang), karang mati, dan mix (campuran karang mati, rubble, dan pasir). Persen tutupan $\mathrm{R}$ di areal terumbu ST2 lebih tinggi dari tiga areal terumbu lain, sementara RCK memiliki persen tutupan tinggi di areal terumbu ST1. Komponen pasir memiliki nilai persen tutupan substrat dasar yang tinggi di areal terumbu ST4 dan terendah pada ST1, tetapi tidak ditemukan di ST2. Persen tutupan R lebih tinggi pada semua areal terumbu menunjukan areal terumbu karang tepi ini, terutama ST2 telah mendapat tekanan antropogenik yang signifikan.

Terumbu karang Dusun Pelita Jaya memiliki 22 bentuk tumbuh bentik, kondisi ini sama dengan Sangaji (2012) yang menemukan total bentuk tumbuh bentik terumbu karang di perairan Pelita Jaya yang terdiri atas 22 kategori. Kenyataan ini menunjukan bahwa kualitas perairan Pelita Jaya sangat mendukung bagi pertumbuhan keanekaragaan bentuk tumbuh bentik. Menurut English et al (1997), total bentuk tumbuh bentik suatu terumbu karang alami adalah 29 kategori. Hal ini menggambarkan bahwa keragaman bentuk tumbuh bentik di terumbu karang tepi Pelita Jaya tergolong tinggi, yaitu mencapai $79 \%$ dari total bentuk tumbuh bentik terumbu karang alami. Keragaman bentuk tumbuh bentik terumbu karang perairan Pelita Jaya lebih tinggi dari beberapa lokasi di Maluku seperti di Dusun Olas dengan 16 bentuk tumbuh bentik (Rahim, 2010) dan Dusun Katapang dengan 19 kategori (Widayati, 2015).

Bentuk tumbuh bentik di ST4 lebih tinggi (20 kategori), diikuti ST1 dan ST2 (17 kategori), dan terendah di areal terumbu karang ST3. Hal ini disebabkan kesesuaian substrat areal terumbu ST4 yang menunjang kehadiran bentuk tumbuh bentik dengan variasi tinggi. Fakta sebaliknya, variasi bentuk tumbuh yang rendah pada areal terumbu ST3 karena substrat dasar terumbu relatif kurang sesuai untuk kehadiran bentuk-bentuk tumbuh bentik tertentu. Bila ditelusuri menurut kelompok bentuk tumbuh maka $60 \%$ karang Acropora dan $75 \%$ karang Non-Acropora serta $77 \%$ bentuk tumbuh karang 
ditemukan di areal terumbu Dusun Pelita Jaya. Karang Acropora bentuk tumbuh Encrusting (ACE) dan Submassive (ACS), serta karang Non-Acropora bentuk tumbuh submassive (CS) dan Heliopora (CHL) tidak menempati terumbu karang ini. Hanya 80\% bentuk tumbuh Algae, 75\% fauna lain dan komponen abiotik menempati areal terumbu karang. Berbasis hasil analisis, karang Non-Acropora bentuk tumbuh CE tidak menempati areal terumbu ST1, ST3 dan ST4, sementara CME tidak ditemukan di areal terumbu ST2 dan ST3.

\section{c. Status Kerentanan Terumbu Karang}

Kerentanan merupakan ukuran tinggi atau rendahnya kemampuan organisme untuk dapat menjalankan fungsinya. Semakin tinggi tingkat kerentanan maka pertumbuhan dan perkembangan suatu organisme akan mengarah pada kondisi ketidakstabilan organisme dalam menjalankan fungsinya, dan sebaliknya. Kerentanan terumbu karang dapat memberikan ukuran kualitas kesehatan terumbu karang. Semakin tinggi tingkat kerentanan terumbu karang, maka kualitas kesehatan terumbu karang dikategorikan dalam kondisi buruk, dan semakin rendah tingkat kerentanan terumbu karang maka kualitas terumbu karang dikatakan baik. Berbasis nilai persen penutupan terumbu karang dan kriteria penilaian status kerentanan terumbu karang, maka terlihat jelas bahwa status kerentanan terumbu karang di perairan Pelita Jaya secara keseluruhan digolongkan dalam kategori highly vulnerability (kerentanan tinggi). Bila tekanan antropogenik terus terjadi di areal terumbu ST3 dan ST1, maka kondisi terumbunnya akan masuk kategori extrime vulnerability (kerentanan sangat tinggi) yang mengarah pada kerusakan terumbu karang pada skala yang lebih besar yang berujung pada kepunahan. Fakta ini menunjukan bahwa degradasi terumbu karang perairan Pelita Jaya membutuhkan langkah-langkah pengelolaan yang dapat mengurangi kegiatan antropogenik di lingkungan sekitarnya

\section{KESIMPULAN}

1. Kondisi lingkungan perairan Pelita Jaya sangat mendukung bagi pertumbuhan dan perkembangan ekosistem terumbu karang. Parameter-paramater fisik perairan yang diperlukan terumbu karang masih tergolong normal dan sangat layak bagi kehidupan terumbu karang.

2. Perairan Pelita Jaya memiliki potensi taksa karang batu yang terdiri atas 83 spesies karang batu yang termasuk dalam 34 genera dan 14 family, serta memiliki komponen penyusun terumbu karang yang terdiri atas tiga komponen utama abiotik, yaitu Sand (S), Rubble (R) dan Rock (RCK), dimana R dan RCK mendominasi komponen abiotik.

3. Status terumbu karang di perairan Pelita Jaya Provinsi Maluku pada umumnya berada dalam kategori highly vulnaribility (kerentanan tinggi). Bila tekanan antropogenik

BIOLOGI SEL (YOL 6 NO 1 EDISI JAN-JUN 2017 ISSN 2252-858X/E-ISSN 2541-1225) PAGE 34 
terus terjadi areal terumbu, maka kondisi terumbunnya akan masuk kategori extrime vulnerability (kerentanan sangat tinggi).

\section{SARAN}

Penelitian ini hanya menggunakan salah satu paramaeter ekologi untuk mengungkap status kerentanan terumbu karang di Pelita Jaya, untuk itu diperlukan penelitian lanjutan dengan menggunakan beberapa parameter ekologi kerentanan terumbu karang.

\section{DAFTAR PUSTAKA}

Burke, L., E. Selig dan M. Spalding. 2002. Terumbu Karang Yang Terancam di Asia Tenggara. World Resources Institute.

Dahuri, R., J. Rais, S.P. Gintingdan M. J. Sitepu. 2008. Pengelolaan Sumberdaya Wilayah Pesisir dan Lautan Secara Terpadu. Jakarta: Pradnya Paradita.

English, S., C. Wilkinson., and V. Baker. 1997. Survey Manual ForTropical Marine Resources. ASEAN-Australia Marine Science Project: Living Coastl Resources.

KLH. 2001. Keputusan Mentri Negara Lingkungan Hidup Nomor 04 Tahun 2001, Tentang Kriteria Baku Kerusakan Terumbu Karang.

Monk, A. K., Y. de Fretesdan G. Reksodiharjo-Lilley. 2000. Ekologi Nusa Tenggara dan Maluku. Jakarta: Prehallindo.

Nybekken, J. W., 2001. Marine Biology: An Ecological Approach (5 $5^{\text {th }}$ d). Benjamin Cummings: Addison Wesley Longman, Inc.

Rahim, Y. 2010. Aktivitas Pemanfaatan Ikan Karang Yang Berdampak Pada Ekosistem Terumbu Karang di Perairan Pesisir Dusun Olas, Kabupaten Seram Bagian Barat. Skripsi. Fakultas Perikanan dan Ilmu Kelautan Unpatti. (TidakDipublikasi).

Sukarno, M. Hutomo, M. K. Moosa, P. Darsono. 1981. Terumbu Karang di Indonesia. Jakarta: LIPI

Sangaji M. 2012. Rancang Bangun Model Pengelolaan Terumbu Karang Berbasis Resiliensi Eko-Sosio System (Kasus Teluk Kotania Provinsi Maluku). Pascasarjana IPB. Disertasi IPB. (Tidak dipublikasi).

Supriharyono. 2000. Pengelolaan Ekosistem Terumbu Karang. Jakarta: Penerbit Djambatan.

Suharsono. 2008. Jenis-JenisKarang Di Indonesia. Jakarta: LIPI Press.

Tuwo, A.H. 2011. Pengelolaan Ekowisata Pesisir dan Laut: Pendekatan Ekologi, SosialEkonomi, Kelembagaan, dan Sarana Wilayah. Surabaya: Brilian International.

Widayati, S. 2015. Dampak Aktivitas Masyarakat Terhadap Ekosistem Terumbu Karang di Perairan Pesisir Dusun Katapang, Kabupaten Seram Bagian Barat. Skripsi. Fakultas Perikanan dan Ilmu Kelautan Unpatti (Tidak Dipublikasi). 